\title{
ENERGY AND EXERGY ANALYSIS FOR BIOMASS CO-FIRING COAL FUEL BASED THERMAL POWER PLANT
}

\author{
Satyananda Tripathy ${ }^{1}$, Jayanarayan Mahakud ${ }^{2}$, Manmatha K. Roul ${ }^{3}$ \\ ${ }^{I}$ Department of Mechanical Engg, Suddhananda Engineering \& Research Center (SERC), Odisha, India \\ ${ }^{2}$ Department of Mechanical Engg, Parala Maharaja Engineering College (PMEC), Odisha, India \\ ${ }^{3}$ Department of Mechanical Engg Gandhi Institute for Technological Advancement (GITA), Odisha, India
}

\begin{abstract}
Environmental pollution and its control has been one of the most challenging problems to the mankind, especially to the scientific and engineering community. Out of the various environmental polluting sources, excess $\mathrm{CO}_{2}$ in atmosphere is the single largest contributor for global warming effect. This $\mathrm{CO}_{2}$ imbalance in the atmosphere is caused by excessive release of $\mathrm{CO}_{2}$ to the environment from various the man-made industries, like power plants, chemical plants, automobiles, etc. Since coal fuel based power plants are concentrated large source of production of excess $\mathrm{CO}_{2}$, attention is focused on sequestration of $\mathrm{CO}_{2}$ to maintain the environmental $\mathrm{CO}_{2}$ balance. However, due to its cost intensiveness and technological difficulties, implementation of $\mathrm{CO}_{2}$ sequestration option has not been adopted by all. A detailed exergy analysis of the control volume has been carried out considering physical and chemical exergy of all the streams and presented in this dissertation. It has been concluded from the results of this analysis that biomass cofiring option may only be considered as a short-term measure to reduce the $\mathrm{CO}_{2}$ production since the exergy losses including the irreversibility losses are more compared to only coal based power plants.
\end{abstract}

Keywords: Energy and exergy analysis, Biomass co-firing, Thermal power plant, Environmental pollution etc.

\section{THEORETICAL ANALYSIS}

Energy is one of the major inputs for the economic development of any country. In case of the developing countries, the energy sector assumes a critical importance in view of the ever-increasing needs. As the world is becoming more advanced in technology, more energy is being used to keep up with the changing requirements. The world's primary energy resource is the fossil fuel-coal, and if the current rate of utilization of energy is being continued, the world will shortly come to an end of fossil fuel- coal. Hence energy policy is promoting many researches both for the enhancement of utilization of renewable energy and low enthalpy fuels for power generation and for finding the most effective ways of using them.

Coal fired power plants are normally getting the edge over the other possibilities, since coal is abundantly available and the implementation time is relatively short. The major source of energy which is available in India for thermal power plants is coal. In 1947 the total power generation capacity was only $1360 \mathrm{MW}$, and by 1991 it grew to $65000 \mathrm{MW}$, of which $69 \%$ $(45000 \mathrm{MW})$ was generated in thermal power plants. The total installed power generating capacity in India is about 1, 25,000 MWe with coal-based thermal power plants comprising 55\% of the total (Ministry of Power, 2006). The proven global coal reserve was estimated as 984453 million tones at the end of 2003. The USA had the largest share of the global reserve
(25.4\%) followed by Russia (15.9\%), China (11.6\%). India was 4 th in the list with $8.6 \%$. India has huge coal reserves, at least 84396 million tones of proven recoverable reserves (at the end of 2003). This amount to almost $8.6 \%$ of the world reserves and it may last for about 230 years at the current reserve to production $(\mathrm{R} / \mathrm{P})$ ratio. Coal production is concentrated in these states (Andhra Pradesh, Uttar Pradesh, Bihar, Madhya Pradesh, Maharashtra, Orissa, Jharkhand, and West Bengal). According to the present data the present power position in India is approximately $100 \mathrm{GW}$ whereas it is estimated the demand of power will go to $240 \mathrm{GW}$ by the year 2012.

\subsection{Methodologies for System Analysis}

Traditionally, the thermodynamic analysis of any thermal system is carried out with help of the First Law of Thermodynamics. It gives basically the energy utilization scenario of the thermal system in terms of conservation of energy. This kind of analysis, however, is unable to provide information regarding the losses both qualitatively and quantitatively. Moreover it could not locate where these losses actually occur in a system. All these drawbacks are overcome with the application of the exergy concept based on the Second Law of Thermodynamics. The exergy is the maximum amount of theoretical useful work obtainable in bringing the state of the system of interest into state of environment. Thus, exergy is a measure of the departure of the state of a system 
from that of the environment. Unlike energy, exergy can never be conserved; rather some of it is destroyed in any real process. Even though exergy concept was developed in the early part of 20th century, the regular use of exergy analysis started in the second half of the century and became the focus of attention for energy conservation in all kinds of energy applications. Exergy was particularly valuable because it allows a uniform basis to compare between disparate processes. That is why, in recent years there has been a growing trend in the using of Second Law of Thermodynamics in analyzing thermal systems. This analysis provides the information about not only the losses of any thermal systems qualitatively as well as quantitatively, but also their location. The information obtained from the exergy analysis can be used for further improvement in the design and operation of thermal systems. With this information, the design engineers are able to find out the components where exergy destructions are more. Then, the component interdependencies are evaluated to study how the system varies with the design changes in the component.

\subsection{Available Thermodynamic Analysis}

\subsubsection{Energy Analysis}

Several thermodynamic approaches are possible to analyze the operational performance of a thermal power plant. The First Law of Thermodynamics based analysis provides the performance of a thermal system based on conservation of energy. The principle of conservation of energy states that energy can neither be created nor be destroyed, although it can be changed from one form to another. Thus in any isolated or closed system, the sum of all forms of energy remains constant. Of particular interest is the special form of the principle known as the principle of conservation of mechanical energy which states that the mechanical energy of any system of bodies connected together in any way is conserved, provided that the system is free of all frictional forces, including internal friction that could rise during collisions of the bodies of the system [1]. However, First Law analysis does not clarify where and why there are performance degradations, which are mainly due to irreversibilities generated in system or process whereas, The Second Law analysis determines the magnitude and direction of irreversible processes in a system and thereby provides an indicator that points the direction in which engineers should concentrate their efforts to improve the performance of the thermal systems.

\subsubsection{Exergy Analysis}

The second law analysis is based on the concept of exergy The term exergy was introduced by Rant in 1953, which is extensively discussed in the books of Kotas and Szargut et al. [13]. A possibility to work exists whenever a system at a given state interacts with another system at a different state, while they are allowed to come into an equilibrium state. Assuming one of the two systems as environment and the other as system of interest, exergy or availability can be defined as the maximum amount of theoretical useful work obtainable in bringing the state of the system of interest into the state of the environment. Based on this analysis one can find out all the irreversible losses through exergy destruction, thus provides the real picture of the performance of any thermal system. Thus, this tool becomes very important in analyzing any thermal system.

All the work that has been published with biomass co-firing coal-fired power plants shows only the energy analysis and environmental impact of reducing emission of $\mathrm{CO} 2, \mathrm{SO} 2$, and NOx .Therefore the exergy analysis for biomass co-firing coal fuel based power plant is considered in the present work to achieve at the flowing objectives

- To study the important of biomass co-firing in coal fuel based power plant.

- To study the various co-firing option in coal fuel based power plant.

- To study the exergy analysis of a biomass co-firing in coal fuel based power plant.

According to the given data the coal used in the plant is eastern bituminous coal with $1.9 \%$ sulphur, $7.2 \%$ moisture, $8.8 \%$ ash, and $31751 \mathrm{~kJ} / \mathrm{kg}$ of Higher Heating Value (HHV).The ultimate analysis of eastern bituminous coal gives the detailed chemical composition of different constituents which are tabulated in Table 1.

\subsection{Energy and Material Balances}

The energy and material balances for baseline coal only and $15 \%$ co-firing option has already been done on the plant and given in Table 1 and Table 2, respectively.

\subsection{Assumptions for Analysis}

1) The environment is treated as at $27^{\circ} \mathrm{c}$.

2) The air required for combustion is considered to be $21 \%$ oxygen and $79 \%$ nitrogen on molar basis and on mass basis it is $23.2 \%$ oxygen and $76.8 \%$ nitrogen.

Table 1 Energy Balance of the plant (GJ/hr)

\begin{tabular}{|l|l|l|}
\hline Heat In & $\begin{array}{l}\text { Baseline } \\
\text { Coal Only }\end{array}$ & $\begin{array}{l}15 \% \quad \text { Co- } \\
\text { fired }\end{array}$ \\
\hline Coal & 1092.9 & 940.6 \\
Biomass & 1092.9 & 166.6 \\
\hline Total & & \\
\hline Heat Out & 360.6 \\
\hline Net steam turbine output & 360.1 & 360.1 \\
Auxiliary power use & 23.0 & 23.0 \\
Condenser & 587.0 & 587.0 \\
Stack gas loss & 97.6 & 112.1 \\
Boiler radiation losses & 3.4 & 3.4 \\
\hline
\end{tabular}




\begin{tabular}{|l|l|l|}
\hline Unburned carbon loss & 5.5 & 4.4 \\
Unaccounted for boiler heat & 16.4 & 16.6 \\
loss & 1092.9 & 1106.6 \\
Total & & \\
\hline
\end{tabular}

Table 2 Material Balance of the plant $(\mathrm{Mg} / \mathrm{hr})$

\begin{tabular}{|l|l|l|}
\hline Mass In & $\begin{array}{l}\text { Baseline Coal } \\
\text { Only }\end{array}$ & $15 \%$ Co-fired \\
\hline Coal & 37.1 & 31.9 \\
Biomass & & 11.1 \\
Combustion air & 525.3 & 533.0 \\
Lime stone & 0.0 & 0.0 \\
Feed Water Makeup & 0.0 & 0.0 \\
Total & 562.4 & 576.0 \\
\hline Mass Out & & \\
\hline Bottom ash & 0.7 & 0.6 \\
Fly ash & 2.8 & 2.4 \\
Flue gas & 558.9 & 573.0 \\
Gypsum & 0.0 & 0.0 \\
Total & 562.4 & 576.0 \\
\hline
\end{tabular}

3) The air and combustion gases are treated as ideal gas behavior

4) The nitrogen present in the combustion air is inert in nature and has no effect in chemical reaction.

5) The flue gas is consisting of $\mathrm{CO}_{2}, \mathrm{SO}_{2}, \mathrm{H}_{2} \mathrm{O}_{\text {gas }}, \mathrm{O}_{2}$, and $\mathrm{N}_{2}$.

\section{RESULTS AND DISCUSSIONS}

\subsection{Operating Plant Data at Various State Point}

The success of any thermodynamic analysis of an existing plant depends upon the accurate operational data. The operational data at various state points with reference to the control volume shown in Figure 1 is tabulated in Table 3.

Table 3: Operational Data for the Plant

\begin{tabular}{|c|c|c|c|c|c|}
\hline State & Components & Pressure & Tempe & Mass & $(\mathrm{Mg} / \mathrm{hr})$ \\
\hline Points & & ( Bar ) & $\begin{array}{l}\text { rature } \\
\left({ }^{0} c\right)\end{array}$ & $\begin{array}{l}\text { Coal } \\
\text { Only }\end{array}$ & $\begin{array}{l}15 \% \\
\text { Cofiring }\end{array}$ \\
\hline 1 & Coal In & 1.01325 & 27 & 37.1 & 31.9 \\
\hline 2 & Biomass In & 1.01325 & 27 & 0 & 11.1 \\
\hline 3 & $\begin{array}{l}\text { Combustion } \\
\text { Air In }\end{array}$ & 1.01325 & 38 & 525.3 & 533 \\
\hline 4 & Steam Out & 165 & 538 & 0.842 & 0.842 \\
\hline 5 & $\begin{array}{l}\text { Flue gas with } \\
\text { fly ash }\end{array}$ & 1.01325 & 129 & $\begin{array}{l}558.9 \\
2.8 \\
\end{array}$ & \begin{tabular}{|l|}
573 \\
2.4 \\
\end{tabular} \\
\hline 0 & Bottom Out & 1.01325 & 1327 & 0.7 & 0.6 \\
\hline
\end{tabular}

\subsection{Calculation of Physical Exergy}

To calculate the physical exergy the properties data such as enthalpy and entropy data of respective state points corresponding to their temperature is first needed. The same is calculated first and summarized in Table6.3. In the present work data for properties evaluation is taken from NISTJANAF Thermochemical Tables and for super heated steam by Moran and Shapiro [1].

\section{State Point 1 and 2}

The enthalpy of any fuel is its higher heating value (HHV). The HHV for coal and biomass are shown in Table 1 and 2, respectively.

\section{State Point 3}

The air considered being ideal gas mixture consisting of $21 \%$ oxygen and $79 \%$ nitrogen by molar basis. It is entering to the boiler at $38^{\circ} \mathrm{c}=311.15 \mathrm{~K}$.

According to the Eqs. (4.19) and (4.20) the enthalpy and entropy be respectively

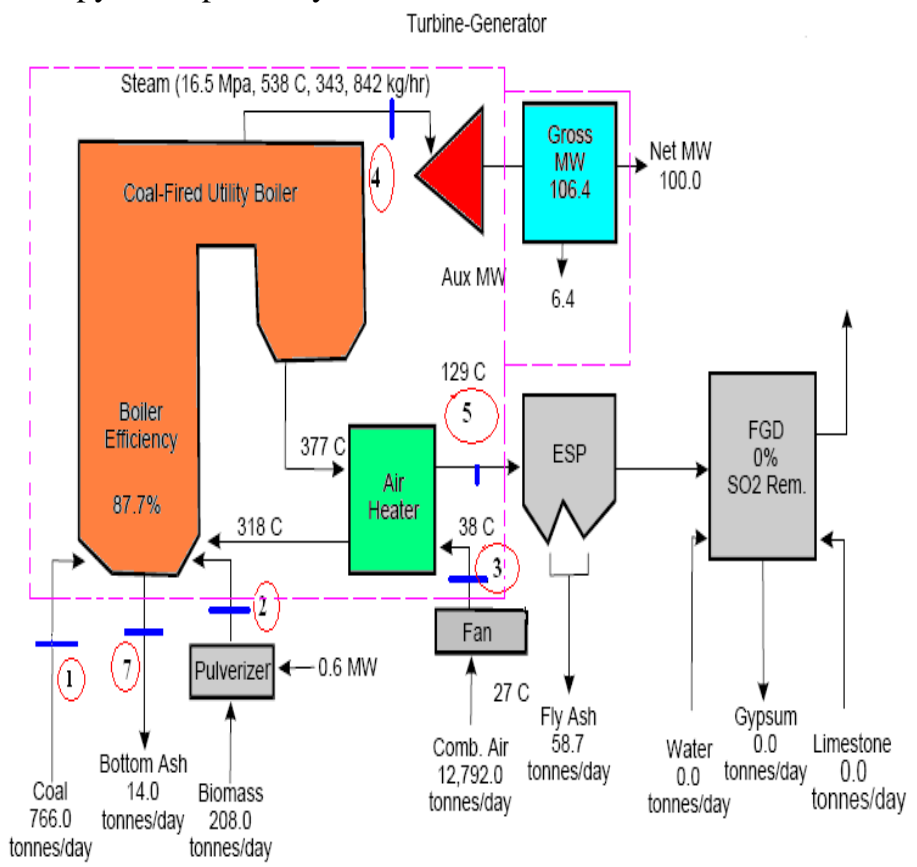

Fig 1 Control Volume for the Plant

$$
\begin{aligned}
& \bar{h}_{3}=0.21 \times \bar{h}_{O_{2}}+0.79 \times \bar{h}_{N_{2}}=379.84681 \mathrm{~kJ} / \mathrm{kmol} \\
& \bar{s}_{3}=0.21 \times \bar{s}_{O_{2}}+0.79 \times \bar{s}_{N_{2}}=199.91028 \mathrm{~kJ} / \mathrm{kmol} . \mathrm{K}
\end{aligned}
$$

\section{State Point 4}

At this point the steam is leaving at temperature $538^{\circ} \mathrm{c}$ and 165 bar

From the super heated steam data it is interpolated between 160 barand 180 bar and found to be 


$$
\bar{h}_{4}=3404.778 \mathrm{~kJ} / \mathrm{kg} \text { and } \bar{s}_{4}=6.4181 \mathrm{~kJ} / \mathrm{kg} . \mathrm{K}
$$

\section{State point 5}

The state point 5 is consists of flue gas along with fly ash. The enthalpy of this point is the summation of two. Using chemical formula for coal and biomass from Table 5.3.1 and 5.3.2 respectively and with chemical reaction of Eq. (4.13) the composition of the flue gas is found out and summarized in Table 4.

Table 4 Composition of Flue Gas

\begin{tabular}{|c|c|c|}
\hline \multirow{2}{*}{ Constituent } & \multicolumn{2}{|c|}{$\mathrm{kmol} / 100 \mathrm{~kg}$} \\
\cline { 2 - 3 } & $\mathrm{Coal}$ & Biomass \\
\hline $\mathrm{CO}_{2}$ & 11.47 & 11.82 \\
$\mathrm{SO}_{2}$ & 0.12 & 0.004 \\
$\mathrm{H}_{2} \mathrm{O}$ & 5.43 & 12.5 \\
$\mathrm{O}_{2}$ & 6.76 & 6.2 \\
$\mathrm{~N}_{2}$ & 76.22 & 69.482 \\
\hline
\end{tabular}

The enthalpy and entropy of flue gas using Eqs (4.19) and (4.20) is

$\bar{h}_{\text {flue gas }}=-55513.99363 \mathrm{~kJ} / \mathrm{kmol}$

$\bar{s}_{\text {flue gas }}=207.3768443 \mathrm{~kJ} / \mathrm{kmol} . \mathrm{K}$

With the data from Table 5.3.3 we have

$\bar{h}_{\text {fly ash }}=-1006576.361 \mathrm{~kJ} / \mathrm{kmol}$.

$\bar{s}_{f l y ~ a s h}=94.39433565 \mathrm{~kJ} / \mathrm{kmol} . \mathrm{K}$

\section{State Point 6}

Through state point 6 the bottom ash taken out at temperature $1600 \mathrm{~K}$. Similar to the above procedure and same equation the properties at point 6 is

$\bar{h}_{6}=0.52 \times \bar{h}_{\mathrm{SiO}_{2}}+0.21 \times \bar{h}_{\mathrm{Al}_{2} \mathrm{O}_{3}}+0.0102 \times \bar{h}_{\mathrm{TiO}_{2}}+$

$$
\begin{aligned}
& =-899294.3887 \mathrm{~kJ} / \mathrm{kmol} \\
\bar{s}_{6} & =0.52 \times \bar{s}_{\mathrm{SiO}_{2}}+0.21 \times \bar{s}_{\mathrm{Al}_{2} \mathrm{O}_{3}}+0.0102 \times \bar{s}_{\mathrm{TiO}_{2}}+ \\
& =217.7493 \mathrm{~kJ} / \mathrm{kmol} . \mathrm{K}
\end{aligned}
$$

\section{Physical Exergy for Baseline Coal Only}

$+0.0125 \times \bar{h}_{\mathrm{Na}_{2} \mathrm{O}}+0.02 \times \bar{h}_{\mathrm{K}_{2} \mathrm{O}}$

Table $\mathbf{6}_{2} \mathrm{C}$ hemical Exergy values on the state points.

Using the equations above data the physical exergy at all

\begin{tabular}{|c|c|c|c|}
\hline $\begin{array}{l}\text { State } \\
\text { Points }\end{array}$ & $\begin{array}{c}\text { Enthalpy } \\
(\mathrm{kJ} / \mathrm{kmol})\end{array}$ & $\begin{array}{c}\text { Entropy } \\
(\mathrm{kJ} / \mathrm{kmol} . \mathrm{K})\end{array}$ & $\begin{array}{l}\text { Physical } \\
\text { Exergy } \\
(\mathrm{GJ} / \mathrm{hr})\end{array}$ \\
\hline 1 & $\mathrm{HHV}^{\mathrm{a}}$ & & 0 \\
\hline 2 & $\mathrm{HHV}^{\mathrm{b}}$ & & 0 \\
\hline 3 & 379.84681 & 199.91028 & 0.44262 \\
\hline 4 & 3404.778 & 6.4181 & 1.249967 \\
\hline 5 & $\begin{array}{c}-55513.99363 \\
\text { for flue gas and } \\
-1006576.361 \\
\text { for fly ash }\end{array}$ & $\begin{array}{c}207.3768443 \text { for } \\
\text { flue gas and } \\
94.3943565 \text { for fly } \\
\text { ash }\end{array}$ & 231.9763 \\
\hline 6 & \begin{tabular}{|l|}
-899294.3887 \\
\end{tabular} & 217.7493 & 0.580248 \\
\hline
\end{tabular}
points are calculated and shown in Table 5 for coal only and in Table 5 for $15 \%$ co-firing.

Table 5 Physical Exergy for Baseline Coal Only

Table 5 Physical Exergy for 15\% Co-firing

\begin{tabular}{|c|c|c|c|}
\hline $\begin{array}{c}\text { State } \\
\text { Point } \\
\mathrm{s}\end{array}$ & $\begin{array}{c}\text { Enthalpy } \\
(\mathrm{kJ} / \mathrm{kmol})\end{array}$ & $\begin{array}{c}\text { Entropy } \\
(\mathrm{kJ} / \mathrm{kmol} . \mathrm{K})\end{array}$ & $\begin{array}{c}\text { Physical } \\
\text { Exergy } \\
(\mathrm{GJ} / \mathrm{hr})\end{array}$ \\
\hline 1 & $\mathrm{HHV}^{\mathrm{a}}$ & & 0 \\
\hline 2 & $\mathrm{HHV}^{\mathrm{b}}$ & & 0 \\
\hline 3 & 379.84681 & 199.91028 & 0.4490566 \\
\hline 4 & 3404.778 & 6.4181 & 1.25 \\
\hline 5 & $\begin{array}{c}-58242.07809 \text { for } \\
\text { flue gas and }-\end{array}$ & $\begin{array}{c}211.0118484 \text { for flue } \\
\text { gas and } 94.82284036 \\
\text { for fly ash }\end{array}$ & 13.6593238 \\
\hline 6 & $\begin{array}{c}-867719.773 \text { for fly } \\
\text { ash }\end{array}$ & $\begin{array}{c}\text { 214.4715163 } \\
\text { (267627 }\end{array}$ & 0.467897 \\
\hline
\end{tabular}

\subsection{Calculation of Chemical Exergy}

The chemical exergy of the solid fuel is calculated by using Eqs. (4.21), (4.22), and (4.23), and that for other state points

\begin{tabular}{|c|c|c|}
\hline $\begin{array}{c}\times \mathbb{S t a t e ~}_{\mathrm{Sta}_{2}}+ \\
\text { Points }\end{array}$ & $\begin{array}{c}\text { Chemical } \\
\text { OEQ2ryy }\left(G_{2} J / h r\right) \\
\text { for } \\
\text { Baseline Coal Only }\end{array}$ & $\begin{array}{l}\text { Chemical } \\
\text { Exergy }(G J / h r) \\
\text { for } 15 \% \text { Co-firing }\end{array}$ \\
\hline 1 & 1041.13 & 895.6882 \\
\hline 2 & -- & 172.3145 \\
\hline 3 & 0 & 0 \\
\hline
\end{tabular}
by using Eqs. (4.9) and (4.10). The chemical exergy data for elements are taken from [27]. All these calculated value are elements are taken fror 


\begin{tabular}{|c|c|c|}
\hline 4 & 0.04212 & 0.04212 \\
\hline 5 & 37.76015671 & 36.802 \\
\hline 6 & 0.573048 & 0.632 \\
\hline
\end{tabular}

\subsection{Total Exergy Calculation}

The total exergy is the summation of physical exergy and chemical exergy. The total exergy for base coal line and 15\% co-firing at all state points are tabulated in Table 7

Table 7 Total Exergy values on the state points

\begin{tabular}{|c|c|c|}
\hline \multirow{2}{*}{$\begin{array}{c}\text { State } \\
\text { Points }\end{array}$} & \multicolumn{2}{|c|}{ Total Exergy $(\mathrm{GJ} / \mathrm{hr})$} \\
\cline { 2 - 3 } & Baseline Coal Only & $15 \%$ Co-firing \\
\hline 1 & 1041.13 & 895.6882 \\
\hline 2 & -- & 172.3145 \\
\hline 3 & 0.44 & 0.45 \\
\hline
\end{tabular}

\begin{tabular}{|c|c|c|}
\hline 4 & 1.292087 & 1.29212 \\
\hline 5 & 269.7364567 & 50.4613238 \\
\hline 6 & 1.153296 & 1.099897 \\
\hline
\end{tabular}

\subsection{Exergy Losses}

The exergy losses, in general, can be written as

$$
\dot{E}_{L}=\dot{E}_{1}+\dot{E}_{2}+\dot{E}_{3}-\dot{P}-\dot{E}_{5}-\dot{E}_{6}
$$

Using the above calculated value of exergy rate at state points the exergy losses for base coal and $15 \%$ co-firing, respectively, are:

$$
\begin{aligned}
& \dot{E}_{l}(\text { coal })=1041.13+0+0.44262-360.0-269.7364567-1.153296=410.68 \mathrm{GJ} / \mathrm{hr} \\
& \dot{E}_{L}(\text { Co }- \text { firing })=895.6882+172.315+0.4490566-360.0-50.4613238-1.099897 \\
& \quad=656.89 \mathrm{GJ} / \mathrm{hr}
\end{aligned}
$$

From the above calculated value of exergy losses it is seen that the exergy losses for the co-firing option is more than that of baseline coal. Since from the energy balance data for the plant shows the stack gas loss $97.6 \mathrm{GJ} / \mathrm{hr}$, boiler radiation losses 3.4 $\mathrm{GJ} / \mathrm{hr}$, unburned carbon loss $5.5 \mathrm{GJ} / \mathrm{hr}$, unaccounted for boiler heat loss $16.4 \mathrm{GJ} / \mathrm{hr}$ for coal only and that of $15 \%$ co-firing are $112.1 \mathrm{GJ} / \mathrm{hr}, 3.4 \mathrm{GJ} / \mathrm{hr}, 4.4 \mathrm{GJ} / \mathrm{hr}$, and $16.6 \mathrm{GJ} / \mathrm{hr}$, respectively, this exergy losses corresponding to these energy losses are included in the above calculated exergy loss values for both the cases.

\section{CONCLUSIONS}

Based on the obtained results presented in this dissertation, the following important inferences can be drawn:

- The chemical exergy of fuel in case of biomass cofiring is more than that of coal-only case by $2.58 \%$.

- The total exergy value of flue gas with fly ash in case of biomass co-firing is less by $81.29 \%$ compared to that of baseline coal case.

- The total exergy value of bottom ash in case of biomass co-firing is less by $4.63 \%$ compared to that of baseline coal case.

- The exergy losses including irreversibility losses are more for biomass co-firing by $59.95 \%$ as compared to coal-only case.

- The available energy losses through emission products, like fly ash, bottom ash, etc., can be comprehensively reduced by co-firing biomass in a coal fuel based power plant.

- Since total irreversibility losses including exergy losses corresponding to the unaccounted boiler heat losses is more in case of biomass co-firing compared to that of baseline coal case, the biomass co-firing is not an acceptable option for prolong use.

- Considering environmental friendliness to certain extent, the biomass co-firing option in coal fuel based power plants can be considered as a short-term stopgap measure to reduce environmental pollution. It may continue till some technologically sound and cost effective measures of $\mathrm{CO}_{2}$ sequestration options are available for the coal based thermal power plants.

\section{REFERENCES}

[1] Moran, M.J., Shapiro, H.N., 2000, Fundamentals of Engineering Thermodynamics, John Wiley \& Sons, Inc., New York.

[2] Franco, A., Russo, A., 2002, "Combined Cycle Plant Efficiency Increase Based onthe Optimization of the Heat Recovery Steam Generator Operating Parameters"International Journal of Thermal Sciences", Vol. 41, pp. 843-859.

[3] Franco, A., Casarosa, C, 2002, "On Some Perspectives for increasing the efficiency of Combined Cycle Power 
Plants" Applied Thermal Engineering, Vol. 22, pp. 1501-1518.

[4] Narayanana, K.V, Natarajanb, E, 2007, "Experimental studies on co-firing of coal and biomass blends in India" Renewable Energy, Vol 32, No.15, pp. 25482558.

[5] Chikkatur, A.P., Sagar, A.D., Abhyankar, N., and Sreekumar, N., 2007, "Tariff-based incentives for improving coal-power-plant efficiencies in India", Energy Policy, Vol. 35, Issue 7, Pp. 3744-3758

[6] Savolaien, K., 2003, "Co-firing of biomass in coal-fired utility boilers". Applied Energy, Vol. 74, PP. 369-381

[7] Tillman, D. A., Hus, P. J., 2000, "Co-firing multiple opportunity fuels with coal at Bailly Generating Station". Biomass and Bioenergy, Vol. 19, PP. 385-394

[8] Hansen, K. W., Overgaard, P., and Larse O. H., 2000, "Co-firing coal and straw in a $150 \mathrm{MW}_{\mathrm{e}}$ power boiler experiences". Biomass and Bioenergy Vol. 19, Issue 6, PP. 395-409 